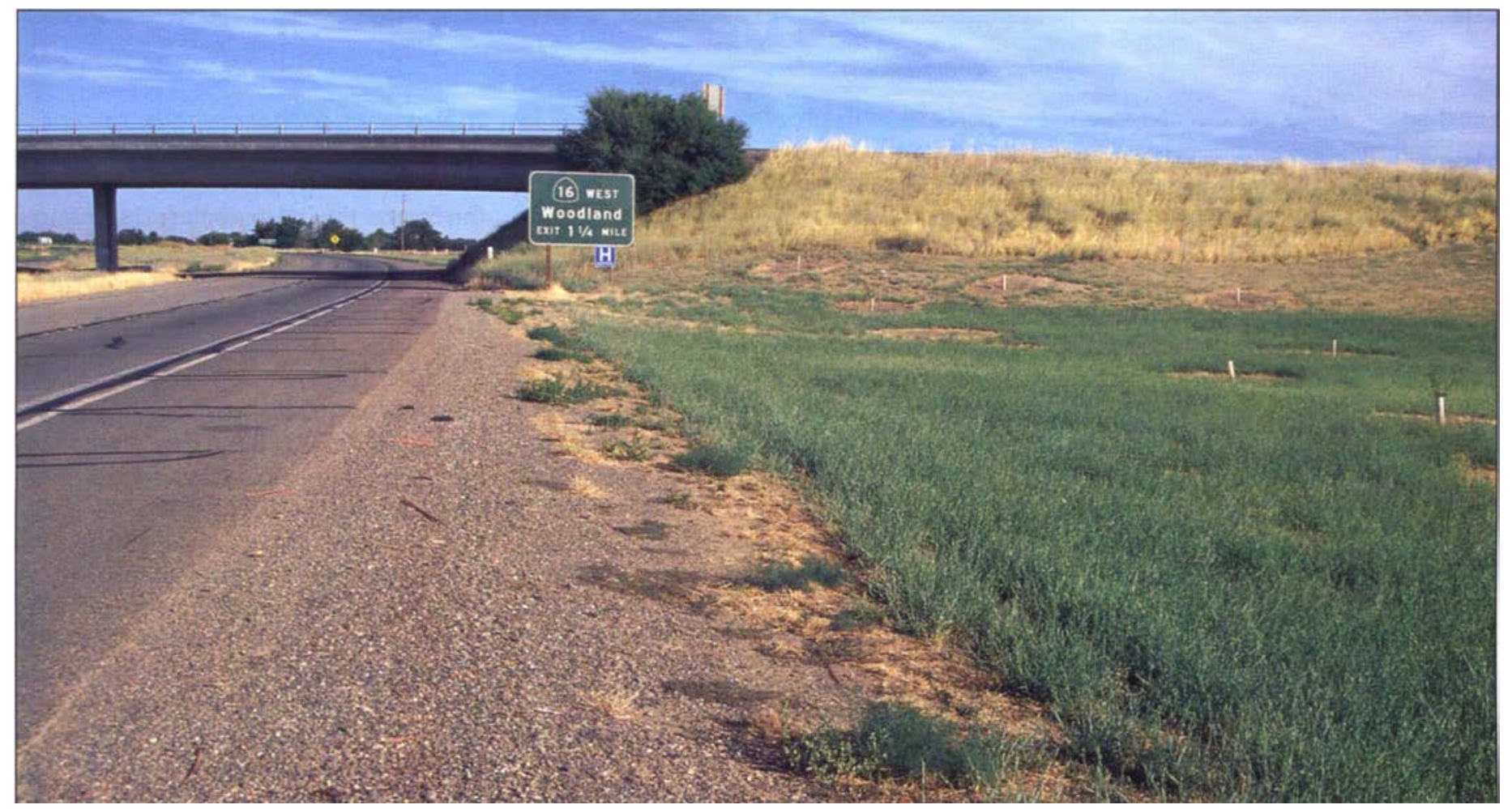

Hoadside mowing for fire suppression in late spring can lead to an increase in the yellow starthistle population as seen in the right of this photo.

\title{
Success of mowing to control yellow starthistle depends on timing and plant's branching form
}

\author{
Carri B. Benefield a Joseph M. DiTomaso a Guy B. Kyser a Steve B. Orloff \\ Kenneth R. Churches $\square$ Daniel B. Marcum $\square$ Glenn A. Nader
}

\begin{abstract}
Successful control of yellow starthistle by mowing depends on both proper timing and the plant's form of growth and branching. The branching habit of yellow starthistle is highly variable and is in part dependent on the level of competition with other species for light. Field studies were conducted in five Northern California counties to examine the effects of growth form, timing of mowing and number of mowings on yellow starthistle growth and seed production. Erect, high-branching populations were effectively controlled by a single mowing at early flowering, while sprawling, low-
\end{abstract}

branching plants were not satisfactorily controlled even by multiple mowings. Mowing should provide an effective tool for yellow starthistle control in an integrated approach with clopyralid treatment, prescribed burning or biological control.

Yellow starthistle, a member of the sunflower family, was first introduced into California from Eurasia (via South America) in the mid-19th century as a contaminant of alfalfa seed (Prather 1994). Today it is the most widespread noncrop weed in California. This invasive plant has a long germination period, a deep taproot with efficient soil moisture usage, and copious seed production with few germination requirements (DiTomaso et al. 1999). Such characteristics typically lead to the exclusion of desirable species in rangelands, roadsides, parks and disturbed urban lands. In these sites, yellow starthistle displaces existing species, decreases the recreational value of lands and reduces forage productivity and grazing capacity. It can also be poisonous to horses when consumed in large quantities (Callihan et al. 1995; DiTomaso et al. 1999).

Starthistle (Centaurea solstitialis L.) is considered a long-lived winter annual. In California, germination occurs with the first fall/winter rain. Development continues into spring when 
starthistle forms a basal rosette, sends up a bolting stalk and develops spiny seedheads. Starthistle flowers throughout summer and eventually senesces in late summer or early fall. However, there is a wide variation in development depending on climatic and environmental parameters such as elevation, precipitation, and soil depth and type.

Mowing can be an economical and effective method for controlling yellow starthistle. Prior studies have shown that the timing of mowing is critical (Thomsen et al. 1996, 1997; Vayssieres et al. 1994). If mowed at an early growth phase such as bolting, starthistle rapidly recovers. In contrast, if mowing is delayed until a large number of flowers are open, plants will not fully recover but viable seed will be produced.

An effective, long-term yellow starthistle control program is based on eliminating or at least significantly reducing further seed production. Even when yellow starthistle is mowed at early flowering, the growth stage believed to be most effective, results are not always favorable. We conducted field studies in five Northern California counties to identify the parameters

TABLE 1. Effects of multiple mows on seedhead production, dry weight and height of individual plants at final harvest, Yolo County

\begin{tabular}{lccc}
\hline \hline $\begin{array}{l}\text { Stage at mowing and } \\
\text { Number of cuttings }\end{array}$ & Seedheads/plant & Dry weight & Height \\
\hline & $g /$ plant & $\mathrm{cm} /$ plant & $119 \mathrm{a}$ \\
Control & $2,439 \mathrm{a}^{*}$ & $828 \mathrm{a}$ & $98 \mathrm{~b}$ \\
Bolting 1X & $2,166 \mathrm{a}$ & $752 \mathrm{a}$ & $88 \mathrm{c}$ \\
Bolting 2X & $1,266 \mathrm{~b}$ & $484 \mathrm{~b}$ & $83 \mathrm{c}$ \\
Spiny 1X & $1,040 \mathrm{bc}$ & $443 \mathrm{~b}$ & $45 \mathrm{e}$ \\
Spiny 2X & $754 \mathrm{c}$ & $229 \mathrm{c}$ & $55 \mathrm{~d}$ \\
Early flowering 1X & $811 \mathrm{bc}$ & $265 \mathrm{c}$ & $28 \mathrm{f}$ \\
Early flowering 2X & $596 \mathrm{c}$ & $154 \mathrm{c}$ & \\
\hline
\end{tabular}

"Means followed by the same letter are not significantly different $(P<0.05)$ for treatments (columns).

TABLE 2. County site parameters

\begin{tabular}{|c|c|c|c|c|c|}
\hline & \multicolumn{5}{|c|}{ Counties } \\
\hline & Butte & Calaveras & Shasta & Siskiyou & Yolo \\
\hline Elevation (ft) & 185 & 1,100 & 3,300 & 2,631 & 60 \\
\hline $\begin{array}{l}\text { Rainfall (in.) } \\
\text { average } \\
\text { field season }\end{array}$ & $\begin{array}{c}25 \\
25.3(7 / 96-6 / 97)\end{array}$ & $\begin{array}{c}22 \\
24.3\end{array}$ & $\begin{array}{c}18 \\
21.4\end{array}$ & $\begin{array}{c}18 \\
27.6\end{array}$ & $\begin{array}{c}18 \\
16.5\end{array}$ \\
\hline $\begin{array}{l}\text { Soil depth } \\
\text { and type }\end{array}$ & $\begin{array}{c}30-35 \text { in. } \\
\text { Keefers gravelly } \\
\text { loam }\end{array}$ & $\begin{array}{l}10-28 \text { in. } \\
\text { Auburn schist } \\
\text { calcareous }\end{array}$ & $\begin{array}{c}60 \text { in., alluvial } \\
\text { Dotta sandy loam }\end{array}$ & $\begin{array}{l}\text { moderately deep } \\
\text { Duzel gravelly }\end{array}$ & $\begin{array}{l}\text { deep alluvial } \\
\text { Yolo silty loam }\end{array}$ \\
\hline $\begin{array}{l}\text { Yellow } \\
\text { starthistle } \\
\text { life cycle }\end{array}$ & $\begin{array}{l}\text { Germinate: } \\
\text { Nov-Mar } \\
\text { Bolt: } \\
\text { early May } \\
\text { Flower: late } \\
\text { May-Jun } \\
\text { Senesce: } \\
\text { Jul-Aug }\end{array}$ & $\begin{array}{l}\text { Germinate: } \\
\text { Oct-late spring } \\
\text { Bolt: late May- } \\
\text { early Jun } \\
\text { Flower: } \\
\text { late Jun-Jul } \\
\text { Senesce: } \\
\text { late Jul-Aug }\end{array}$ & $\begin{array}{c}\text { Germinate: } \\
\text { Feb-Apr } \\
\text { Bolt: May-Jun } \\
\text { Flower: } \\
\text { Jul } \\
\text { Senesce: } \\
\text { Sep-Oct }\end{array}$ & $\begin{array}{l}\text { Germinate: } \\
\text { Oct-May } \\
\text { Bolt: May- } \\
\text { early Jun } \\
\text { Flower: } \\
\text { Jun-Aug } \\
\text { Senesce: } \\
\text { Sep-Oct }\end{array}$ & $\begin{array}{c}\text { Germinate: } \\
\text { Nov-Jun } \\
\text { Bolt: May-Jun } \\
\text { Flower: } \\
\text { Jun-Sep } \\
\text { Senesce: } \\
\text { Aug-Sep }\end{array}$ \\
\hline $\begin{array}{l}\text { Species } \\
\text { present }\end{array}$ & $\begin{array}{l}\text { old yellow } \\
\text { starthistle } \\
\text { skeletons, soft } \\
\text { chess, wild oats, } \\
\text { ripgut brome }\end{array}$ & $\begin{array}{l}\text { wild oats, brome, } \\
\text { tarweed }\end{array}$ & $\begin{array}{c}\text { downy brome, } \\
\text { bulbous } \\
\text { bluegrass, } \\
\text { California } \\
\text { poppy }\end{array}$ & $\begin{array}{l}\text { no other } \\
\text { species } \\
\text { present, } \\
\text { solid stand } \\
\text { of yellow } \\
\text { starthistle }\end{array}$ & $\begin{array}{l}\text { no other } \\
\text { species } \\
\text { present, } \\
\text { solid stand } \\
\text { of yellow } \\
\text { starthistle }\end{array}$ \\
\hline $\begin{array}{l}\text { Mowing } \\
\text { technique }\end{array}$ & $\begin{array}{l}\text { high-wheel } \\
\text { rotary mower } \\
\text { or sickle bar } \\
\text { mower } 3-4 \text { in. } \\
\text { mowing height }\end{array}$ & $\begin{array}{l}\text { DR brush } \\
\text { mower ( } 8 \text { horse- } \\
\text { power rotary } \\
\text { mower) } 3-4 \text { in. } \\
\text { mowing height }\end{array}$ & $\begin{array}{c}\text { MTD (5 horse- } \\
\text { power } 21 \text { in.) } \\
4 \text { in. mowing } \\
\text { height }\end{array}$ & $\begin{array}{l}\text { self-propelled } \\
\text { sickle-bar } \\
\text { mower } 3-4 \text { in. } \\
\text { mowing height }\end{array}$ & $\begin{array}{c}\text { garden shears } \\
4 \text { in. } \\
\text { mowing } \\
\text { height }\end{array}$ \\
\hline
\end{tabular}

contributing to the most effective use of mowing for yellow starthistle control. To accomplish this, we examined the interaction of growth form, number of mowings and developmental stage on yellow starthistle growth and seed production.

\section{Yolo County}

Site preparation. In November 1995 a field site in Yolo County was treated with metam sodium to eliminate all preexisting weed seeds and then seeded with yellow starthistle in December. We used a randomized, complete block design with four replicates of each treatment. Each plot was 5 feet by 10 feet $(1.5 \mathrm{~m}$ by $3 \mathrm{~m})$ with starthistle plants at 2 -feet $(0.6 \mathrm{~m})$ spacing in two rows, 2 feet apart. Plots were hand-weeded and starthistle seedlings thinned to 8 to 12 plants per plot (table 1).

Mowing height. Treatments consisted of uncut controls and five mowing heights: $0,2,4,6$ and 8 inches $(0,5$, 10,15 and $20 \mathrm{~cm}$ ). All treatments were mowed and plant material removed from plots at early flowering ( $2 \%$ to $5 \%$ ) in late June 1996. Plants were allowed to recover and then harvested at senescence at the end of the season. Plant height, dry weight and seedhead numbers were measured at harvest.

Plants from plots mowed to $2,4,6$ or 8 inches recovered to approximately half the height of the unmowed controls. Plants mowed to ground level did not survive. All mowing treatments resulted in significant reductions in seedhead number (fig. 1), plant height and dry weight (data not shown). However, there were no statistical differences among 2-, 4-, 6- or 8 -inch mowing treatments. Despite the reduction in seedhead number following a single mowing, a sufficient number of seeds were produced to reinfest sites in subsequent years.

While mowing at ground level was found to be an effective means of control, this method is impractical, especially in rocky, debris-laden terrain. It does suggest that hand-held weeders or hoes may provide effective control of yellow starthistle when plants are cut at ground level. 
In contrast, mowing blades are typically 4 inches above the soil surface. Mowing at heights greater than or equal to 2 inches is not likely to reduce an existing yellow starthistle population or to adequately decrease new seed recruitment. Although mowing under these conditions proved ineffective, in the Yolo County study yellow starthistle was grown without competing vegetation and as a result developed a low-branching pattern, which allowed for rapid recovery following cutting.

\section{Mowing timing and frequency.}

Treatments consisted of uncut controls and combinations of one, two or three mowings conducted at three stages of development: bolting, spiny and early flowering. The bolting stage was characterized by the development of elongated stems. The subsequent appearance of flowerhead buds with well-developed spines was classified as the spiny stage. Early flowering stage consisted of $2 \%$ to $5 \%$ of the spiny buds transitioning into the flowering stage.

Garden shears and cutting blocks were used to ensure a uniform 4 -inch $(10 \mathrm{~cm})$ cutting height. Height and dry weight of cut plants were recorded for each mowing. In addition, seedhead number per plant was estimated from representative samples taken at plant senescence. These values were used to estimate potential seed production per unit area.

Plants mowed at the spiny and flowering growth stages were shorter and produced less biomass and fewer seedheads in comparison to plants mowed at earlier stages (table 1). Multiple mowings further reduced biomass and seedhead production. The greatest reductions in all measured parameters were achieved with two mowings at spiny stage, and one or two mowings at early flowering. Reduction in height was proportional to the reduction in biomass and seedhead production. It is also important to note that mowing late in the season (spiny and early flowering) delayed senescence and allowed plants to continue seed production well into winter.

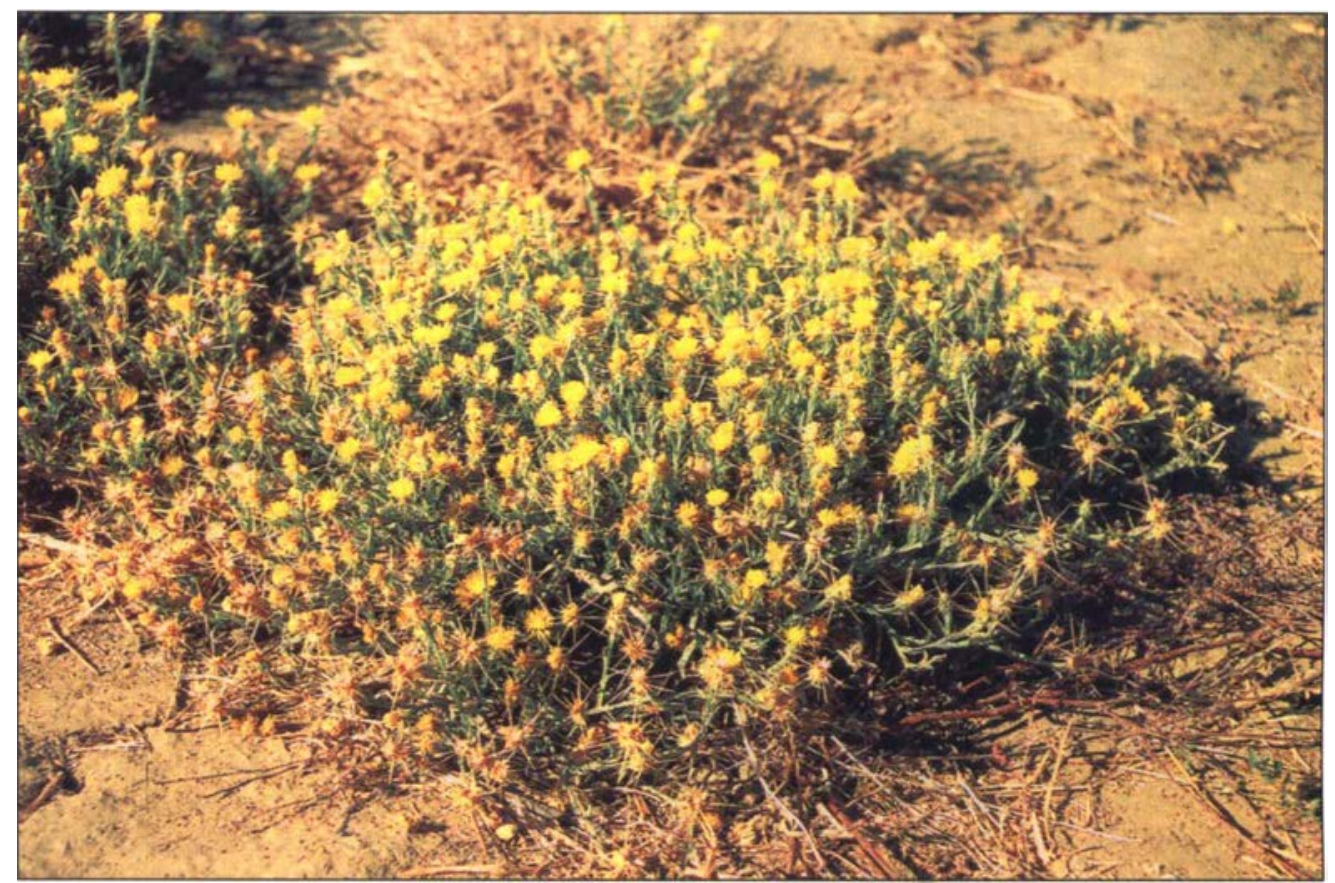

Yellow starthistle with numerous basal branches was mowed three times at early flowering.

In these Yolo County plots all plants were grown in the absence of competing vegetation. This permitted them to develop large and rounded forms, with a low branching pattern and numerous stems arising from near the base of the plant. Regardless of the stage of development or the number of cuttings, mowing was ineffective in controlling these large, low-branching plants. Even though seed production was dramatically reduced with multiple mowing at spiny or early flowering stages, an estimated 20,000 seeds were still produced per plant. A lowbranching pattern may render mowing ineffective, regardless of the stage of development or frequency of mowing.

\section{Butte, Calaveras, Shasta, Siskiyou}

Site parameters. Due to the importance of branching height in our Yolo County trial, mowing experiments were conducted in existing yellow starthistle infestations in Butte, Calaveras, Shasta and Siskiyou counties in 1997. Plots were 10 feet by 10 feet ( $3 \mathrm{~m}$ by $3 \mathrm{~m}$ ) in a randomized, complete-block design (four replicates). In Butte, Calaveras and Shasta counties, plants were growing with competing vegetation, primarily annual grasses. Populations of starthistle in Siskiyou County were much denser
( $>400$ plants $/ \mathrm{ft}^{2}$ ) compared to the average density at the other sites $(<50$ plants $\left./ \mathrm{ft}^{2}\right)$ and had few additional plant species present (table 2).

The effect of light on branching height was investigated in Yolo County (1997) by measuring differences in yellow starthistle growth form under full sun and $15 \%$ full sun using shade cloth. The height of the lowest three branches of mature plants was measured in 20 plants at both light levels.

Growth form. In starthistledominated areas with little competi-

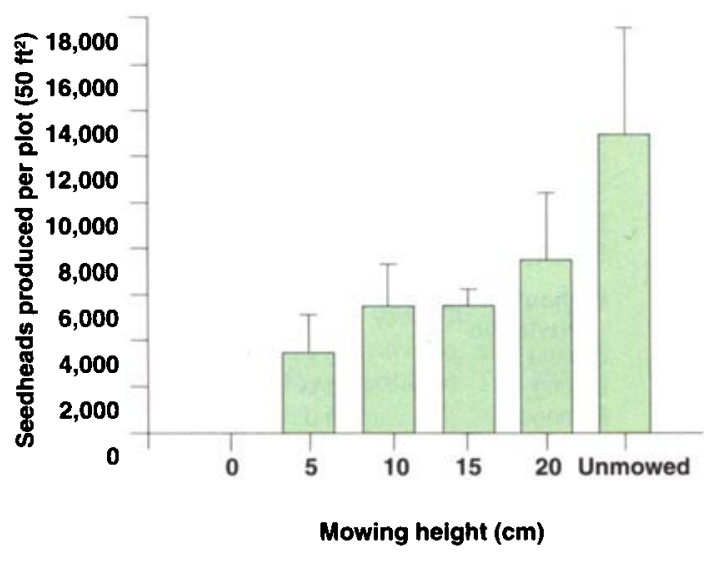

Fig. 1. Effect of mowing to different heights on yellow starthistle seed head production, Yolo County. 
tion from other species, most plants developed a low-branching pattern. These plants were large with ample basal branching within 4 inches $(<10$ $\mathrm{cm}$ ) of the soil surface, analogous to the Yolo County plants. In contrast, starthistle infestations in areas with significant competition, particularly from annual grasses, tended to develop a more erect growth form and a higher branching pattern with the first branch usually above 4 inches.

The development of larger plants with a low-branching pattern was promoted in Butte and Calaveras counties by mowing competing vegetation when yellow starthistle was at the rosette stage. Subsequently, yellow starthistle was thinned by hoeing and plots were treated with a postemergence grass-selective herbicide, sethoxydim or fluazifop.

In Shasta County, plots were treated with a postemergence grassselective herbicide, but not initially mowed or thinned. In Siskiyou

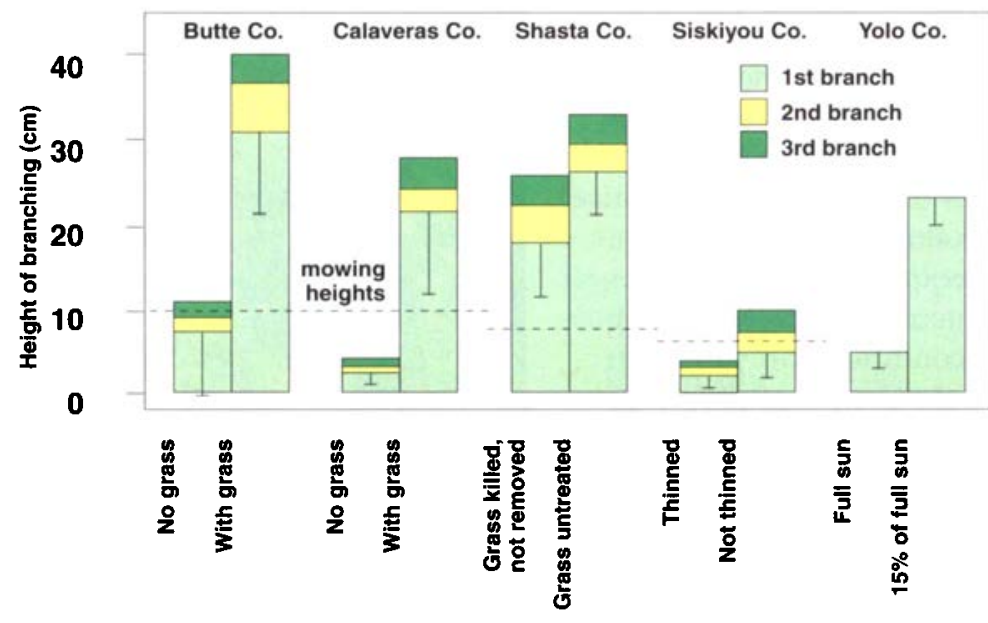

Fig. 2. Changes in yellow starthistle branching habit with competition or shading. Error bars represent sample standard deviation for height of first branch.
County, dense yellow starthistle plots were thinned by randomly placing 8 ounce cups over starthistle plants $(25$ remainder of the plot with glyphosate. At harvest, heights of the three lowest branches were measured on plants in the unmowed control, cups within each plot) and treating the

TABLE 3. Treatment schedule

\begin{tabular}{|c|c|c|c|c|c|c|c|c|}
\hline \multirow[b]{3}{*}{ County } & \multirow[b]{3}{*}{ Established } & \multicolumn{6}{|c|}{ Mowed stage and number of mowings } & \multirow[b]{3}{*}{ Harvest } \\
\hline & & \multicolumn{2}{|c|}{ Bolting } & \multicolumn{2}{|c|}{ Spiny } & \multicolumn{2}{|c|}{ Early flowering } & \\
\hline & & $1 \mathrm{X}$ & $2 X$ & $1 \mathrm{X}$ & $2 \mathrm{x}$ & $1 \mathrm{X}$ & $2 x$ & \\
\hline Butte & Apr 8 & May 29 & Jun 26 & Jun 9 & Jul 3 & Jun 26 & Jul 3 & Aug 12 \\
\hline Calaveras & Apr 21 & May 27 & Jun 17 & Jun 6 & Jul 7 & Jun 17 & Jul 7 & Aug 21 \\
\hline Shasta & May 21 & Jun 23 & Jul 25 & Jul 6 & Aug 1 & Jul 20 & Aug 12 & Sep 3 \\
\hline Siskiyou & Apr 25 & Jun 7 & Jun 26 & Jun 24 & Jul 18 & Jul 9 & Aug 9 & Oct 1 \\
\hline Yolo & Feb 15 & Jun 4 & Jun 24 & Jun 12 & Jul 15 & Jun 30 & Aug 1 & Oct 15 \\
\hline
\end{tabular}

TABLE 4. Dry weight and seedhead production in four California counties, 1997

\begin{tabular}{|c|c|c|c|c|c|c|c|c|}
\hline \multirow[b]{2}{*}{ Treatments } & \multicolumn{4}{|c|}{ Dry weight $\left(g / \mathrm{m}^{2}\right)$} & \multicolumn{4}{|c|}{ Seedheads $/ \mathrm{m}^{2}$} \\
\hline & Butte & Calaveras & Shasta & Siskiyou & Butte & Calaveras & Shasta S & Siskiyou \\
\hline \multicolumn{9}{|l|}{$\begin{array}{l}\text { With competing } \\
\text { vegetation }\end{array}$} \\
\hline Control & $71 \mathrm{~b}^{*}$ & $118 \mathrm{a}$ & 74 bc & - & $183 \mathrm{bc}$ & 936 a & $338 \mathrm{~b}$ & - \\
\hline Bolting $1 \mathrm{X}$ & $16 \mathrm{c}$ & $33 \mathrm{bc}$ & $60 \mathrm{bcd}$ & - & 50 ef & $184 \mathrm{bc}$ & $336 \mathrm{~b}$ & - \\
\hline Bolting $2 X$ & $4 \mathrm{c}$ & $38 \mathrm{bc}$ & 41 cde & - & 12 ef & $169 \mathrm{bc}$ & $257 \mathrm{bc}$ & - \\
\hline Spiny $1 \mathrm{X}$ & $11 \mathrm{c}$ & $45 \mathrm{bc}$ & $51 \mathrm{~cd}$ & - & 41 ef & $186 \mathrm{bc}$ & $260 \mathrm{bc}$ & - \\
\hline Spiny $2 X$ & $1 \mathrm{c}$ & $19 \mathrm{c}$ & 15 efg & - & $2 f$ & $94 \mathrm{c}$ & 97 cde & - \\
\hline Early flowering $1 \mathrm{X}$ & $1 c$ & $14 \mathrm{c}$ & 10 efg & - & $4 f$ & $95 \mathrm{c}$ & 58 de & - \\
\hline Early flowering $2 \mathrm{X}$ & $0.3 \mathrm{c}$ & $9 \mathrm{c}$ & $2 \mathrm{~g}$ & - & $1 f$ & $44 \mathrm{c}$ & $15 \mathrm{e}$ & - \\
\hline \multicolumn{9}{|l|}{$\begin{array}{l}\text { Without competing } \\
\text { vegetation }\end{array}$} \\
\hline Control & $186 \mathrm{a}$ & $-t$ & $116 \mathrm{a}$ & - & $416 a$ & - & 579 a & - \\
\hline Bolting $1 \mathrm{X}$ & $73 b$ & $64 b$ & $95 a b$ & $258 \mathrm{ab}$ & 204 b & $353 \mathrm{~b}$ & 597 a & $1,281 \mathrm{a}$ \\
\hline Bolting $2 X$ & $24 c$ & $39 \mathrm{bc}$ & 37 def & $267 \mathrm{ab}$ & 71 de & $263 \mathrm{bc}$ & $273 \mathrm{bc}$ & $1,386 \mathrm{a}$ \\
\hline Spiny $1 \mathrm{X}$ & $54 \mathrm{~b}$ & $59 \mathrm{~b}$ & 35 defg & $326 \mathrm{a}$ & $129 \mathrm{~cd}$ & $394 \mathrm{~b}$ & 238 bcd & $1,484 \mathrm{a}$ \\
\hline Spiny $2 X$ & $20 c$ & $44 \mathrm{bc}$ & 28 defg & 178 bc & 65 e & $213 b c$ & 196 bcde & 844 b \\
\hline Early flowering $1 \mathrm{X}$ & $15 \mathrm{c}$ & $37 \mathrm{bc}$ & $5 \mathrm{fg}$ & $117 \mathrm{cde}$ & 44 ef & $187 \mathrm{bc}$ & 54 de & 594 bcd \\
\hline Early flowering $2 X$ & $5 c$ & $44 \mathrm{bc}$ & 7 efg & 45 ef & 16 ef & $195 \mathrm{bc}$ & 60 de & 232 def \\
\hline
\end{tabular}

*Means followed by the same letter are not significantly different $(P<0.05)$ for treatments (columns) within each county.

tData not available. thinned and unthinned plots. Dry weight and seedhead production per unit area were measured at the end of the season.

Starthistle with competing vegetation in Butte, Calaveras and Shasta counties developed a high-branching pattern and erect growth form with few basal branches (fig. 2). In Butte and Calaveras counties, low-branching plants developed when plots with yellow starthistle in the rosette stage were mowed, thinned and treated with a postemergence grass-selective herbicide. In contrast to Butte and Calaveras counties, the height of the initial branches in Shasta County were similar in the untreated control plots and the plots treated with a graminicide but not further mowed or thinned.

Yellow starthistle was the predominant species in the Siskiyou County plots. Plants in thinned plots developed a very low-branching pattern. However, even in unthinned plots, dominant individuals out-competed smaller yellow starthistle plants and developed a relatively low-branching pattern. For comparative purposes, plants in Yolo County were shaded with black shade cloth ( $15 \%$ full sun), to simulate shading by competing vegetation as seen in Butte, Calaveras and Shasta counties.

Mowing timing and frequency. Treatments included unmowed controls, with and without thinning, and six mowing treatments in both the low- and high-branching pattern plots. 
The six mowing treatments included: (1) mowed once at bolting; (2) mowed twice, initially at bolting and again when plants recovered to bolting; (3) mowed once at spiny stage; (4) mowed twice, initially at spiny stage and again when plants recovered to spiny stage;

(5) mowed once at early flowering ( $2 \%$ to $5 \%$ ); and (6) mowed twice, initially at early flowering and again when plants recovered to early flowering (table 3).

In all cases, mowing at early flowering most effectively reduced dry weight and seedhead production (table 4). A single mowing at the bolting or spiny stages provided some reduction in dry weight and seedhead number, but this level of control is not sufficient to have any long-term impact. Bolting was the least effective growth stage for repeated mowing treatments. At the early flowering stage, yellow starthistle plants would have depleted more soil moisture than plants at early phases of development, including the bolting and spiny stages. Consequently, recovery of plants mowed at later stages of growth would be reduced by the lack of available soil moisture. Mowing once at early flowering was at least as effective as mowing twice at the spiny stage of development. Although mowing twice at early flowering produced the best control, this was not significantly different from mowing once at early flowering.

In counties with two distinct branching patterns (Butte and Calaveras), mowing plots with competing vegetation (high-branching pattern) resulted in consistently lower yellow starthistle seedhead numbers and dry weights than mowing plots without competing vegetation (table 4). In Shasta County there was a smaller difference in dry weight and seedhead production because plots with competing vegetation were treated with a grass-selective herbicide but not further mowed or thinned. The plots in Siskiyou County were nearly solid stands of yellow starthistle with no significant competing vegetation. These plots resulted in significantly greater dry weight and seedhead production in comparison to other coun- ties. Despite dramatic reductions in seedhead production in comparison to untreated controls, some seedheads were still produced in all plots, even with starthistle plants that developed a high-branching pattern.

\section{Best suppression techniques}

Mechanical control of yellow starthistle can be achieved by detaching shoots at the ground level by hoeing, hand-pulling or hand-held weeders. However, this is impractical and difficult to achieve using a mower on most types of terrain. Successful implementation of mowing for yellow starthistle control depends on both proper timing and plant growth form. Mowing at early flowering ( $2 \%$ to $5 \%$ bloom), at a 4-inch blade height resulted in the most effective reduction of yellow starthistle seedhead number and biomass.

Mowing at early stages typically did not adequately reduce regrowth and seed production. By comparison, mowing at late flowering stages allowed the production of viable seed, perpetuating the seed bank. The effectiveness of mowing is likely to depend on the branching pattern of plants within the infestation. Regardless of the stage of development or number of cuttings, mowing was much less successful in controlling plants with a low-branching pattern.

Many options for starthistle control are expensive or present potential environmental hazards. In areas with a significant annual grass population, yellow starthistle growth is not only suppressed by the competing grasses, but its growth form becomes more erect with a high-branching pattern and little, if any, basal foliage. Under this condition, mowing provides an effective and economical technique for the suppression of yellow starthistle. However, while mowing has the potential to be successful for starthistle control, continued efforts using chemical or nonchemical methods will be required for sustainable management.

C.B. Benefield is Graduate Student, J.M. DiTomaso is Non-Crop Extension Weed Ecologist, and G.B. Kyser is Staff Research Associate, Department of Vegetable

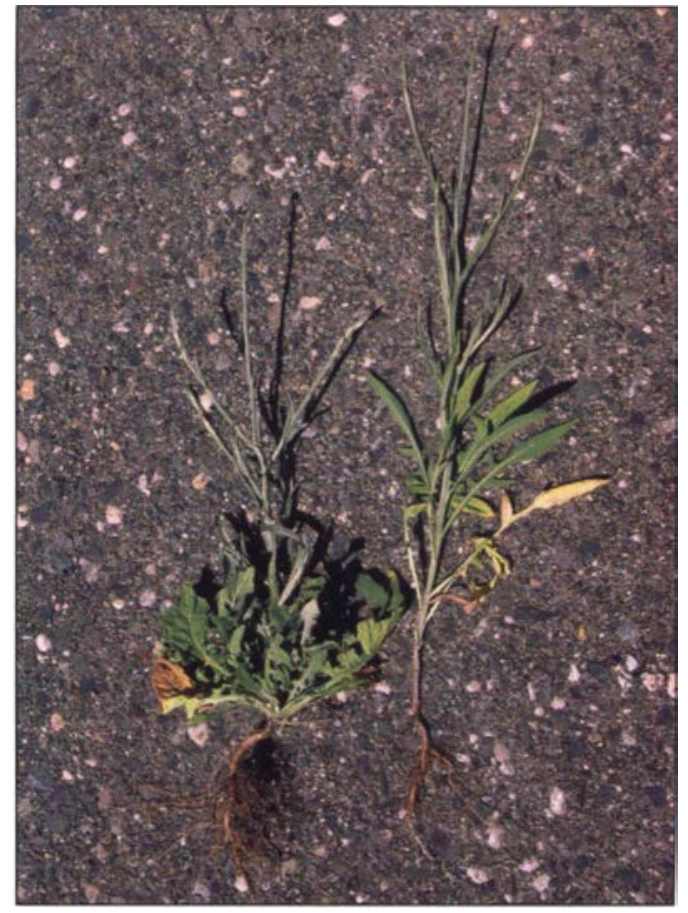

Comparison between yellow starthistle with basal foliage and branching growing in open site and plant with little basal branching and no foliage in grassland area.

Crops, UC Davis; S.B. Orloff, K.R. Churches, D.B. Marcum, and G.A. Nader are Farm Advisors, Siskiyou, Calaveras, Shasta-Lassen, and Sutter-Yuba-Butte counties, respectively.

The authors thank Jenny Drewitz, Stephen Enloe, John Finkelstein, Evelyn Healy, Kevin Karabian, Mark Renz and Alison Tschohl for their assistance with field experiments.

This research was supported by SmithLever IPM Project No. 97SLO17.

\section{References}

Callihan R, Smith L, Michalson EL. 1995. Yellow starthistle management for small acreage. Univ of Idaho College of $\mathrm{Ag}$ Current Info. Series CIS No. 1025:4.

DiTomaso JM, Lanini WT, Thomsen CD, Prather TS, et al. 1999. Pest Notes: Yellow starthistle. UC Division of $\mathrm{Ag}$ and $\mathrm{Nat} \mathrm{Re}-$ sources, No. $7402.4 \mathrm{p}$.

Prather T. 1994. Biology of yellow starthistle. Proceedings, Calif. Weed Sci Soc. Conf. 46:219-23.

Thomsen CD, Williams WA, Olkowski W, Pratt DW. 1996. Grazing, mowing, and clover plantings control yellow starthistle. The IPM Practitioner XVIII (2):1-4.

Thomsen CD, Vayssieres MP, Williams WA. 1997. Mowing and subclover plantings suppress yellow starthistle. Cal Ag 51(6):1520.

Vayssieres MP, Thomsen CD, Williams WA. 1994. Controlling yellow starthistle by mowing. Proceedings, Calif. Weed Sci Soc. Conf. 46:260. 